\title{
IMPACT OF EXTERNAL DEBT ON ECONOMIC GROWTH IN NIGERIA
}

\author{
Timothy Ogbemudiare Ideh ${ }^{i}$ \\ Maria Chinecherem Uzonwanne \\ Department of Economics, \\ Nnamdi Azikiwe University, \\ Awka, Anambra State, \\ Nigeria
}

\begin{abstract}
:
Following the rising spate of the debt profile of Nigeria and the fluctuating trend in her macroeconomic indicators, this study critically examined the impact of external debt on economic growth in Nigeria in the period, 1985 to 2019 by examining the causality between external debt stock and economic growth in Nigeria and identify the impact of external debt servicing on economic growth in Nigeria. The study employed the HarrodDomar theory of economic growth and the Two-Gap model as theoretical framework to explain the impact of external debt on economic growth in Nigeria. The study made use of secondary data sourced from World Development Indicator 2019. Ordinary least square (OLS) technique was adopted for the regression analysis. The data were analyzed with the aid of e-view software (9th edition). The result showed that external debt has negative and insignificant impact on economic growth in Nigeria. Therefore, the study recommended the use of tax revenue to finance public deficit, encouragement of foreign direct investment and domestic investment through improvement in infrastructural facilities and an enabling environment devoid of political and economic instability.
\end{abstract}

JEL: E32, E41, F33, F34, F43

Keywords: external debt servicing, external debt, inflation rate, foreign direct investment inflow, Nigerian economy

\section{Introduction}

Every nation aims to attain and ultimately sustain economic growth for the betterment of her citizenry and the economy as a whole. Economic growth has been defined as a sustained increase in an economy's real national income over a long period of time. In other words, economic growth means a rising trend of net national product at constant

iCorrespondence: email timothyideh2000@gmail.com 
price. To do this, an economy may require an enormous amount of capital, which can be sourced from both internal or domestic and external or foreign means. For third world countries and developing economies who are faced with the paucity of funds to finance major infrastructural projects in their countries, borrowing becomes inevitable (Olasode and Babatunde, 2016). They maintained that the developing countries usually have to seek for funds from internal and external sources to supplement their revenues from taxes and earnings from other means, which are usually low, relative to developed nations.

Developing economy like Nigeria has been known to be deep in heavy and everincreasing external debt [Nigeria Bureau of Statistics (NBS), 2021]. This has crippled numerous attempts with diverse policies and programs aimed at sustainable economic growth. According to the Central Bank of Nigeria (CBN, 2019), the nation has contracted a number of debt obligations from external sources, the pick of which are Paris Club of Creditors, London Club of Creditors, Multilateral Creditors, Promissory Note Creditors, which are the refinanced uninsured trade arrears, Bilateral and Private Sector Creditors. The advent of the nation's rising external debt can be traced back to the oil crisis of the 1970s. The oil price shocks and excessive import reliance of that period instigated a rather unhealthy and chronic debt habit for the economy. Prior to this occurrence, Nigeria had incurred some minor debts from World Bank in 1958 with a loan of US\$28million dollars for railway construction and the Paris' Club debtor nations in 1964 from the Italian government, with a loan of US\$13.1 million for the construction of the Niger dam. The first major borrowing of US\$1 billion known as the "Jumbo loan" was in 1978 from the International Capital Market (ICM) (Adesola, 2009). The nation's total public debt increased by $4.52 \%$ in the first three months of the year 2017, according to the Debt Management Office (DMO) on Wednesday, 21 ${ }^{\text {st }}$ of June 2017. The public debt had increased from 21.73tn (\$71bn) in December 2017 to $22.71 \mathrm{~m}(\$ 74.28 \mathrm{bn})$ at the end of the first quarter of 2018 (Punch, 2018). Between the start of 2015 and December 2020, Nigeria's external debt profile has risen from $\$ 9.7$ billion to $\$ 27$ billion. (Nairametrics, 2020).

The implications of this external debt is that it has led to a division of the nation's scarce resources towards servicing of debt on a yearly basis which further encourages disinvestment in the economy and as a result a fall in the domestic savings and the overall rate of growth. As witnessed, the Nigeria's GDP recorded the highest level in the period 1985 to 2019 in 2004 with a growth rate of 33.74\% and its lowest level of trough in 1987 with a negative growth rate of $-10.75 \%$. In the last decade, economic growth's trend in Nigeria has followed a decline with a negative growth rate of $-1.62 \%$ in 2016 which further culminated into a two consecutive negative economic growth (economic recession) (World Bank, 2019).

For Nigeria, the constant balance of payment deficit has not allowed for capital inflow which will bring about growth and development; given the fact that foreign exchange earnings needed to finance this investment is insufficient. External borrowing may be the only means of gaining access to the resources needed to achieve rapid economic growth. Despite the seeming justification to borrow externally, it is soon discovered to become a perpetual lifeline burden, consequently engendering severe 
economic implications both to immediate and future generation economies, leaving Nigerians with an acute decline in the standard of living, high external dependence, gross social and economic overhead depreciation, currency depreciation, balance of payment disequilibria, exchange rate depreciation and rising inflationary rate (Ijirshar, Joseph and Godoo, 2016).

To salvage the situations, the Debt Management Office (DMO) was established in October, 2000 to work in collaboration with CBN and Federal Ministry of Finance to manage Nigeria's debts. Substantive success was recorded in 2005 during President Olusegun Obasanjo's administration, when the Paris Club group of creditors agreed to cancel $60 \%$ (US\$18 billion) of the US\$30.85 billion owed to it by Nigeria. This debt relief freed the nation from the yearly US\$2.3 billion (N345 billion) debt service burden, yet, these debts are still rising at the expense of the national income as Nigeria's public debt as at March 2018 is placed at N5.787trillion, reaching an all-time high of 29.59168 USD Million in the third quarter of 2018 before resting at \$27billion in 2019 (Usim, 2018; Debt Management Office, 2019; Trading Economics, 2021).

These burden of debt on indebted countries has the tendency of channeling funds to debt servicing, instead of allocating resources to crucial developmental projects (lyoha, 1999 and Amakom, 2003; Paul, 2017). Despite the accumulated debt and debt relief that was granted around 2005 and 2006, basic infrastructure remains in poor state while poverty remained an average of $65 \%$ of the citizen which questions the need for external debt and subsequent benefit for the growth of the Nigerian economy.

It is against this backdrop that the researcher carried out an investigation into the impact of external debt on economic growth in Nigeria with a view to ascertaining a causal relationship between external debt and economic growth.

\section{Literature Review}

\subsection{Economic Growth}

Economic growth is related to the quantitative and sustained increase in the countries per capita output or income accompanied by expansion in its labor force, consumption level, capital and volume of trade (Ijirshar, Joseph and Godoo, 2016). Dwivendi (2002) further opines that economic growth emerges because of sustained increase in per capita output or net national product over a long period. Hence, another qualification of economic growth requires that the national output be composed of goods and services, which satisfy maximum wants of the maximum number of people. Alternatively, Anyanwu (1995) states that economic growth is a steady process of increasing the productive capacity of the economy and hence, of increasing national income characterized by high rates of increasing per capita output and total factor (most especially labour) productivity. From these diverse definitions, we deduce that economic growth is simply an increase in the capacity of an economy to produce goods and services, compared from one period of time to another. 


\subsection{External Debt}

External debt is that portion of a country's debt that is acquired from foreign sources such as foreign corporations, government or financial institutions. They noted that countries borrow from foreign creditors primarily to finance their own excess expenditures, build additional infrastructure, finance recovery from natural disasters, and even to repay its previous external debt. This may, however, lead to a debt cycle -of continuous borrowing, accumulating payment burden, and eventual default (Arnone, Bandiera \& Presbiterio, 2005). According to Ogbeifm (2007), external debt arises as a result of the gap between domestic savings and investment. As the gap widens, debt accumulates, and this makes the country to continually borrow increasing amounts in order to stay afloat. He further defined Nigeria's external debt as the debt owed by the public and private sectors of the Nigerian economy to nonresidents and citizens that is payable in foreign currency, goods and services. Nigeria external debts dated back to pre- independence era when it acquired its first loan of twenty-eight (28) million US dollars from World Bank, to finance the construction of railway. Ayadi and Ayadi (2016) reported that by 1960, the Nigeria's external debt profile had risen to 150 million US dollar. The quest for developmental plans and the need to finance the flamboyant lifestyle of government leaders in Nigeria surged up the country's external debt to 1 billion US dollar by 1971 (Olasode \& Babatunde, 2016).

According to Muhammad \& Fayyaz (2015), external debts affect the economy in different ways, explaining that where efficient use of external debts can bring economic prosperity to a nation, their inefficient use can cause severe damages as well. In essence, what matters most is not the amount of the foreign loans but the ways the loans are used in developmental process in the economy. However, if these loans are used for current consumption, they will have less impact on future economic growth, but if invested rationally in productive sectors of the economy, they will contribute positively to real growth and enhance the productive capacity of the economy. Thus, for the purpose of this study however, external debt is seen as the debt owed by the public and private sectors of the Nigerian economy to non-residents and citizens that is payable in foreign currency, goods and services.

\subsection{Theoretical Literature}

\section{A. Neoclassical Growth Theory}

The neoclassical growth theory, put forward by Robert Solow and Trevor Swan in the 1950s is one of a number of theories or models that try to explain the concept of economic growth. It proposes that output growth results from one or more of three factors; the increase in labor quantity and quality, increase in capital and the improvements in technology. The theory focuses on these three aforementioned factors that impact economic growth: labor, capital, and technology, or more specifically, technological advances. The output per worker (growth per unit of labor) increases with the output per capita (growth per unit of capital) but at a decreasing rate. This is referred to as diminishing marginal returns. Therefore, there will be a point at which labor and capital can be set to reach an equilibrium state. Since a nation can theoretically determine the 
amount of labor and capital necessary to remain at that steady point, it is technological advances that really impact the economic growth. Hence, for the theory, economic growth will not take place unless there are technological advances, and those advances happen by chance. Once an advance has been made, then labor and capital should be adjusted accordingly. It also suggests that if all nations have access to the same technology, then the standard of living will all become equal.

Neoclassical growth model considered two factor production functions with capital and labor as determinants of output. Besides, it added exogenously determined factor, technology, to the production function.

Thus, neoclassical growth model uses the following production function:

$\mathrm{Y}=\mathrm{f}(\mathrm{K}, \mathrm{L}, \mathrm{t})$

Where:

$\mathrm{Y}=$ output;

$\mathrm{K}=$ capital input;

$\mathrm{L}=$ labor input;

$\mathrm{t}=$ technical progress.

The model is guided by the following assumptions like constant returns to scale, existence of perpetual full employment of labor, flexible prices and wages, substitutability of labor, capital and others.

Implications of this model include: the growth rate of output in steady state is exogenous. If the saving rate increases, it increases output per worker by increasing the capital per worker, but the growth rate of output is not affected. Also, growth in per capita income can either be achieved by increased saving or reduced rate of population growth. This will hold if depreciation is allowed ' in the model. A prediction of the model is that in the absence of continuing improvement in technology, growth per worker must ultimately cease. This prediction follows from the assumption of diminishing returns to capital. The model predicts conditional convergence. All countries having similar characteristics like saving rate, population growth rate, technology, etc., that effect growth will converge to the same steady state level.

The weaknesses of the model lie in the fact that it focuses on investment and capital and also, it does not explain why different countries have different investment and productivity rates while its strength lies in the fact that it provides a theory that determines how rich a country is in the long run especially when a fraction of its output is invested. One of the factors affecting the applicability of its model is its predictions about convergence. Convergence is possible if economies are opened up and there is a greater integration of the world's capital markets through the movement of capital. This is likely to lead to a convergence in the levels of output per capita across rich and poor countries. However, data show that there is a tendency towards convergence in per capita output across rich countries but not across rich and poor countries. At the same time, there has been divergence across rich and poor countries, that is, widening income gap. 


\subsection{Empirical Literature}

The aim of public sector's external sourcing of loans is to boost the economic growth and the eventual development of the domestic economy, whilst avoiding adverse internal effects. However, most developing economies are often faced with a subtle and chronic problem of misspending and misappropriation which continues to militate in favour of an ever-increasing external debt. Researchers in economics have therefore, in their bid to investigate the implications of external debt on the economies of indebted nations, come up with diverse views and standpoints.

Ibi and Aganyi (2015) analysed the impact of external debt on economic growth in Nigeria. It uses the variance decomposition and impulse response from Vector Auto Regression (VAR). The study made use of variables like GDP, external debt, inflation, real exchange rate, public investment, ratio of external debt to exports. Based on the twostage data processing, the result reveals that causation between external debt and economic growth is weak in the Nigerian context and external debt could thus not be used to forecast improvement or slowdown in economic growth in Nigeria. Hence, changes in GDP cannot be predicted with changes in external debt. For debt to promote growth in Nigeria, fiscal discipline and high sense of responsibility in handling public funds should be the watchword of Nigerian leaders.

Abula, et al. (2016) studied the impact of public debt on economic development of Nigeria using the ECM method and employing variables such as external debt stock, domestic debt stock, external debt servicing, domestic debt servicing and GDP per capita in Nigeria from 1986-2014. The ECM results revealed that external debt stock and external debt servicing have insignificant negative relationship with economic development in Nigeria. As recommendations therefore, the study proffered that foreign borrowing by private and public organizations should be adequately monitored by the government debt agency - Debt Management Office (DMO) and all the external loans contracted should be reported to the agency so that an up to date record of the 47 volume of debt can be kept.

Udofia and Akpanah (2016) investigated the impact of external debt on economic growth in Nigeria. The issue was empirically examined using the co-integration test and the error correction test for Nigeria over the period 1980 to 2012 on variables like RGDP growth rate, stock of external debt lo GNI ratio, debt service to export earnings ratio, private investment to GDP ratio, primary school enrolment rate, inflation, real exchange rate, population, trade openness. Findings from this study supported the traditional view between external debt and growth. Also, the study found the non-existence of debt overhang problem for Nigeria. Therefore, the study recommends that development activities in Nigeria be financed through increased export earnings spearheaded by export led growth strategy as well as investment in human capital as these can be the best alternative to external debt in the long run.

Mbah, Umunna and Agu (2016) looked at the impact external debt has on economic growth in Nigeria. Time series data were used which spanned from 1970 to 2013. The study adopted ARDL bound testing approach, Johansen co-integration and error correction model of econometric in analyzing the data. The result of Granger 
Causality indicates a unidirectional causality between debt and economic growth. In the same vein, it is depicted that a long run relationships existed among the variables like annual growth rate of GDP, ratio of external debt to GDP, ratio of external debt service stock to GDP, ratio of national expenditure to GDP, and real exchange rate. At the same time external debt is found to have significant negative impact on GDP. The study therefore concludes that Nigeria has not benefited from the dividend accrued to external borrowing which ought to bridge the savings investment gap. Hence, they recommend that government should embark on prudent borrowing and encourage export-oriented growth.

Olasode and Babatunde (2016) modelled some economic theories that explain the causal relationship between external debt and economic growth in the Nigerian economy. They empirically used autoregressive Distributed Lag model to analyze data from 1983-2012 with variables such as GDP for previous year, GDP for present year, GDP, external debt for present year, external debt for previous year. They applied augmented Dickey Fuller and Phillips-Perron unit root test $\mathrm{f}$ to control spurious data. Johansen Cointegration method was employed to test the relationship: among variables. The result from the ordinary least square method shows that there is dual behaviour as lag one of external debt has positive effect while external debt of the present year has a negative effect on the economic performance and recommended that loans obtained should be channeled towards productive uses.

Ugwuegbe, Okafor and Azino (2016) used annual time series data to investigate the effect of external borrowing and foreign aid on economic growth in Nigeria from 1980 to 2013. They used GDP as a parameter for economic growth and external debt, foreign aid, exchange rate regime and foreign reserve as the exogenous variables. Econometric techniques of Ordinary Least Square (OLS) multiple regression, Augmented Dickey Fuller (ADF), Johansen Co integration, Error Correction Method (ECM) were applied. The results showed that external debt has a positive and significant effect on economic growth, while foreign aid has positive and insignificant effect on economic growth in Nigeria. One of its recommendations is that policy makers should ensure that external borrowings are well managed by adopting amongst other debt management strategies "the debt for equality swap programme." Also, the government should put in place policies to encourage efficient utilization of free financial resources.

Paul (2017) analysed the impact of external debt on economic growth of Nigeria. Data from 1985 to 2015 was analysed using the ordinary least square regression, ADF unit root test, Johansen co-integration and error correction test. The study made use of variables such as GDP, external debt services, external debt stock, external reserve, and exchange rate. Findings from the study reveals that debt service payment has negative and insignificant impact on Nigeria's economic growth while external debt stock has positive and significant effect on Nigeria's growth index. The ADF unit root test shows that all the variables are not stationary at levels but at first difference. Johansen cointegration test shows long-run relationship between external debt and growth index (GDP). The causality test indicates unidirectional causality between external debt and GDP. The study therefore recommends that government should apply external loans to 
infrastructural development, improve business environment through legislation; initiate proper debt management policies and substitute external borrowing for human capital development.

Getinet and Ersumo (2020) analyzed the impacts of public external debt on economic growth in Ethiopia with ARDL approach using a time series annual data from 1983-2018. The model considers annual GDP growth rate as a dependent variable. The debt variables including public external debt stock to GDP (PEDSGD), the ratio of debt service stock to GDP (DSSGD) and debt service stock to export (DSSEXP) and other macroeconomic variables such as trade openness(TRD), rate of inflation(INFL) and public expenditure to GDP ratio (NEXPGD) were the explanatory variables. The study used bound testing for co-integration in the long-run and ECM for short-run dynamics. The study showed long-run co-integration, while the speed with which the disequilibrium caused by lack of proper management of external fund in earlier years returns to long-term equilibrium is $60.96 \%$ in the current year as indicated by coefficient of error correction term. As a result, the study recommends that government should properly allocate its external debt for the productive investment and maintain proper and efficient debt management policy. Even though the reviewed study is related to the present study, this study shall domesticate this research using Nigeria as case study.

The justification of this study stems largely from the outcomes of the literatures reviewed on the impact of external debt on economic growth in Nigeria. Having gone through many theoretical and empirical literatures on the subject matter, the researcher has found out that previous researchers had divergent conclusions. Ezeabasili, Isu and Mojekwu (2011), Obademi (2012) and Hassan, Sule and Abu (2015) to mention a few, conclude that the impact of government debt on economic growth is insignificant. Contrarily, Oduabasi, Uzoka\& Anichebe (2018) and Paul (2017) agree that external debt stock exerts a positive and significant effect on GDP. However, most research reviewed base their theoretical framework on theories of external debt and development as against economic growth theory used in this research. This helped us model the Nigerian economy on external debt with a view to capturing our stated objectives.

\section{Material and Methods}

In line with the Harold-Domar theory of growth which stipulates three kinds of growth: warranted growth, actual growth and natural rate of growth. Warranted growth rate is the rate of growth at which the economy does not expand indefinitely or go into recession. Actual growth is the real rateincrease in a country's GDP per year. Natural growth is the growth an economy requires to maintain full employment. Warranted growth rate is given by:

$\mathrm{G}_{W}=\mathrm{DY}_{\mathrm{t}} / \mathrm{Y}_{\mathrm{t}}=\mathrm{k}^{*} \mathrm{~s}$

Where:

$\mathrm{G}_{\mathrm{w}}=$ Warranted growth rate. 
$\mathrm{k}=$ constant capital-output ratio

$\mathrm{s}=$ constant propensity to save

The equation above shows that the rate of growth equals the constant capitaloutput ratio (k) times the constant propensity to save. This can also be called equilibrium growth rate, while $\mathbf{k}$ implies capacity utilization of capital stock. The need for public borrowing arises from the important role of capital in the developmental process of any nation as capital accumulation improves productivity which in turn enhances economic growth. This study examined the impact external debt and other factors may pave on economic growth. Based on the theoretical framework, the model is specified below as follows, to capture the effect of external debt on economic growth in Nigeria:

$\mathrm{RGDP}=\mathrm{f}(\mathrm{EDS}, \mathrm{EDSP}, \mathrm{FDI}, \mathrm{INF}, \mathrm{EXCH}, \mathrm{GFCF})$

Where:

RGDP = real gross domestic product,

EDS = external debt service;

EDSP $=$ External Debt Service Payment;

FDI = Foreign Direct Investment;

INF = Inflation Rate;

$\mathrm{EXCH}=$ Exchange Rate;

$\mathrm{GFCF}=$ Gross Fixed Capital Formation

Mathematically, the model is specified as:

$R G D P_{t}=\beta_{0}+\beta_{1} E D S_{t}+\beta_{2} E D S P_{t}+\beta_{2} F D I_{t}+\beta_{3} I N F_{t}+\beta_{4} E X C H_{t}+\beta_{5} G F C F_{t}$

The model is restated in an econometric form as:

$R G D P_{t}=\beta_{0}+\beta_{1} E D S_{t}+\beta_{2} E D S P_{t}+\beta_{2} F D I_{t}+\beta_{3} I N F_{t}+\beta_{4} E X C H_{t}+\beta_{5} G F C F_{t}+U_{t}$

Modern econometric analytical techniques have been applied to the study, they are given as follows: Co - integration, unit root test and Ordinary Least Square method (OLS) for the data analysis for the purpose of arriving at a dependable and unbiased analysis. Rigorous investigations are made using ADF unit root test to check the stationary property of the variables in the model, should there be any. The purpose of this test is to establish if the time series have a stationary trend and if not stationary, to show the order of integration differencing. A time series is stationary if the mean and variance is constant over time and the value of covariance between two time periods depends only on the distance between the two time periods and not the actual time at which one covariance is computed. The Augmented Dickey Fuller (ADF) (1981) unit root test was also applied in this study. The data used for the study were sourced from the 
Central Bank of Nigeria (CBN) Statistical Bulletin (2019), World Bank Database (2019) and Nigeria Bureau of Statistics (2019).

\section{Presentation and Analysis of Results}

\subsection{Time Series Properties of the Variables}

The Augmented Dickey-Fuller (ADF) unit root test was conducted for each series, and the results are presented in Table 4.2. The ADF test was done with the following hypothesis: Null hypothesis (Ho): Variable contains unit root and hence is nonstationary. Alternative hypothesis (Hi): Variable does not contain unit root and hence is stationary. The decision rule was to reject the null hypothesis if the calculated ADF Test statistic is greater than test critical values.

Table 4.2: Summary of Unit Root Test

\begin{tabular}{|l|c|c|c|c|}
\hline Variable & $\begin{array}{c}\text { ADF statistics } \\
\text { @ level }\end{array}$ & $\begin{array}{c}\text { ADF Statistics } \\
\text { @ 1 1st difference }\end{array}$ & $\begin{array}{c}\text { ADF critical value } \\
\text { @ 0.05 level }\end{array}$ & $\begin{array}{c}\text { Order of } \\
\text { integration }\end{array}$ \\
\hline RGDP & -3.639361 & -------------- & -2954021 & $1(0)$ \\
\hline LNEDS & -2.162080 & -6.445716 & -2.957170 & $1(1)$ \\
\hline LNFDI & -2.033026 & -8.922376 & -2.957110 & $1(1)$ \\
\hline LNEDSP & -1.407656 & -7.757362 & -2.957110 & $1(1)$ \\
\hline LNGFCF & -0.251509 & -8.029068 & -2.957110 & $1(1)$ \\
\hline INF & -3.820784 & ----------- & -2957110 & $1(0)$ \\
\hline REXCH & -4.045970 & -------------- & -9 QS711H & $1(0)$ \\
\hline
\end{tabular}

Source: Researchers' computation using e-view 11(2021).

Table 4.2 shows the summary of the unit root test using augmented dickey fuller (ADF). The result in the table reveals that real gross domestic product, inflation and real exchange rate are stationary at level 1 (0) whereas external debt, foreign direct investment, external debt service and gross fixed capital formation are stationary at first difference $1(1)$.

\subsection{Co-integration Test}

Table 4.3: Johansen Co-integration Rank Test (Trace Statistics)

\begin{tabular}{|l|c|c|c|c|}
\hline Hypothesized No. of CE(s) & Eigen Value & Trace statistics & $\mathbf{0 . 0 5}$ critical value & Prob. $^{* *}$ \\
\hline None** & 0.925722 & 192.1398 & 125.6154 & 0.0000 \\
\hline At most 1 & 0.740453 & 108.9418 & 95.75366 & 0.0045 \\
\hline At most 2 & 0.621350 & 65.77964 & 69.81889 & 0.1007 \\
\hline At most 3 & 0.400230 & 34.70240 & 47.85613 & 0.4638 \\
\hline At most 4 & 0.284694 & 18.34369 & 29.79781 & 0.5408 \\
\hline Almost 5 & 0.211347 & 7.622263 & 15.49471 & 0.5066 \\
\hline At most 6 & 0.000766 & 0.024522 & 3.841466 & 0.8755 \\
\hline
\end{tabular}

Source: Researchers' computation using e-view 11(2021) 
Table 4.4: Co-integration Rank Test (Maximum Eigen value)

\begin{tabular}{|l|c|c|c|c|}
\hline Hypothesized Noof CE(s) & Eigen Value & Maximum Eigen statistics & $\mathbf{0 . 0 5}$ critical value & Prob. $^{* *}$ \\
\hline None $^{* *}$ & 0.925722 & 83.19792 & 46.23142 & 0.0000 \\
\hline At most $1^{*}$ & 0.740453 & 43.16220 & 40.07757 & 0.0248 \\
\hline At most 2 & 0.621350 & 31.07724 & 33.87687 & 0.1041 \\
\hline At most 3 & 0.400230 & 16.35871 & 27.58434 & 0.6352 \\
\hline At most 4 & 0.284694 & 10.72143 & 21.13162 & 0.6750 \\
\hline At most 5 & 0.211347 & 7.597741 & 14.26460 & 0.4211 \\
\hline At most 6 & 0.000766 & 0.024522 & 3.841466 & 0.8755 \\
\hline
\end{tabular}

Source: Researchers' computation using e-view 11(2021).

Table 4.3 and 4.4 present Johansen co-integration test of trace statistics and maximum eigen value. The results indicate one co-integrating equation at 0.05 level. We therefore reject the null hypothesis and conclude that there exists long run relationship among the variables.

\subsection{Pairwise Granger Causality Tests}

In the Granger Causality test, we observed the direction of cause-effect relationship among variables. This provides the basis for determining which of the variable provides the lead for responses by other variables. The Granger causality test results are presented in the table below. A significant F-probability value, at 0.05 level of significance implies that the stated null hypothesis is to be rejected and the alternative accepted.

Table 4.5: Pairwise Granger Causality Tests

\begin{tabular}{|l|c|c|c|}
\hline Null Hypothesis: & Obs & F-Statistic & Prob. \\
\hline RGDP does not Granger Cause EDS & 32 & 0.39145 & 0.2605 \\
\hline EDS does not Granger Cause RGDP & & 0.58512 & 0.1321 \\
\hline
\end{tabular}

Source: Researchers' computation using e-view 11(2021).

Table 4.5 shows granger causality test. The result shows that real GDP and external debt do not affect each other. This means that there is no causal relationship in existence between real GDP and external debt. By implication however, the rising debt stock of the country has not caused growth changes in Nigeria; in the same vein, the economic growth trend in Nigeria has not affected the flow of external debts for the country.

\subsection{Ordinary Least Square Technique}

This technique is used extensively in regression analysis primarily because it is intuitively appealing and mathematically much simpler than the method of maximum likelihood. It produces estimates that are BLUE (best linear unbiased estimator). Below is the summary of the ordinary least square regression result: 
Table 4.6: Summary of Ordinary Least Square Estimation Dependent variable; RGDP

\begin{tabular}{|l|c|c|c|c|}
\hline Variable & Coefficient & Std. error & T-statistics & Prob. $^{* *}$ \\
\hline C & 30.58509 & 6.659596 & 4.592634 & 0.0000 \\
\hline LNEDS & -1.216140 & 1.998726 & 0.608458 & 0.148 \\
\hline INF & -0.233069 & 0.074849 & -3.113855 & 0.0152 \\
\hline LNFDI & 0.424573 & 0.142296 & 2.983731 & 0.0229 \\
\hline LNGFCF & 0.515226 & 0.243261 & 2.117996 & 0.0371 \\
\hline LNEDSP & -0.134486 & 0.061576 & -2.184065 & 0.0318 \\
\hline REXCH & -2.062578 & 2.124591 & -0.970812 & 0.3403 \\
\hline R-squared & Adjusted R- & F-statistics & Prob.(F-statistic) & Durbin-Watson \\
0.914424 & squared 0.892371 & 29.581439 & 0.0000 & statistic 1.703166 \\
\hline
\end{tabular}

Source: Researchers' computation using e-view 11(2021).

The estimated model can be expressed as thus:

$R G D P=30.585-1.216 \operatorname{LnEDS}-0.233 I N F+0.424 \operatorname{LnFDI}+0.515 \operatorname{LnGFCF}-0.134 \operatorname{LnEDSP}$ $-2.062 \mathrm{REXCH}$

\subsection{T-Statistics}

This is the test for individual significance of variables and a variable is significant when the absolute $t$-statistics is greater than the $t_{0.05}$ critical value at $5 \%$ level of significance. Using 5 percent level of significance and 27 degrees of freedom (34-7) will have the value 2.042 from the t-table.

Table 4.7: Summary of T-test

\begin{tabular}{|l|c|c|c|}
\hline Variable & T-statistic & T-critical value at $\mathbf{0 . 0 5}$ & Assessment \\
\hline LNEDS & 0.608458 & 2.052 & Not significant \\
\hline INF & -3.113855 & 2.052 & Significant \\
\hline LNFDI & 2.983731 & 2.052 & Significant \\
\hline LNGFCF & 2.117996 & 2.052 & Significant \\
\hline LNEDSP & -2.184065 & 2.052 & Significant \\
\hline REXCH & 0.970812 & 2.052 & Not significant \\
\hline
\end{tabular}

Source: Researchers' computation (2021).

Table 4.8 presents summary of T-Test. Since the absolute T-statistics of inflation (3.21138), gross fixed capital formation (2.1179), external debt servicing (2.184065) and foreign direct investment (2.98373) are higher than the critical value at 5 percent, we conclude that these variables are significant in explaining economic growth in Nigeria. However external debt (0.608458) and real exchange rate (-0.970812) are not significant in explaining economic growth in Nigeria.

\subsection{Econometric Test}

Here, diagnostic test such as autocorrelation, normality and heteroskcedasticity are carried out in order to incorporate the assumption of ordinary least square. These tests are: 


\subsection{Heteroskedasticity Test}

This is the violation of the assumption of constant variance of the error terms i.e. unequal variance. The Breusch- Pagan- Godfrey test is adopted to check for the presence, of heteroskedasticity in the model. The decision rule is to reject the null hypothesis if chisquare probability is less than 5 percent.

Table 4.9: Heteroscedasticity Test: Breusch- Pagan- Godfrey

\begin{tabular}{|l|c|c|c|}
\hline F-statistic & 1.771615 & Prob. F (6,27) & 0.313 \\
\hline Observed R-squared & 4.0915928 & Prob. Chi-square (6) & 0.1437 \\
\hline Scaled explained SS & 2.775713 & Prob. Chi-square (6) & 0.4962 \\
\hline
\end{tabular}

Source: Researchers' computation using e-view 11(2021).

The table 4.9 shows Heteroscedasticity test. Since the chi-square probability is greater than 5 percent, we conclude that there is absence of heteroscedasticity. In order words, residuals have constant mean and variance which is in line with OLS assumption.

\subsection{Autocorrelation}

This is the correlation between members of series of observations ordered in time. The Durbin-Watson statistics is adopted to check for the presence of auto correlation. The Durbin Watson statistics is 1.70316 which is approximately 2 . We conclude that there is no auto correlation.

\subsection{Normality Test}

Another assumption of OLS is that data must be normally distributed. Here, the JarqueBera probability is used to test for normality. The null hypothesis is that data are normally distributed. The decision rule is to reject the null hypothesis if p-value is less than $5 \%$. The probability of the Jarque-Bera shows that the residuals are normally distributed as p-value is greater than 5 percent.

\section{Discussion of Findings}

This study critically examined the impact of external debt on economic growth in Nigeria within the period, 1985 - 2019 using secondary data sourced from world development indicator 2019. The descriptive statistics shows that the average value of real gross domestic product, inflation, foreign direct investment, gross fixed capital formation and real exchange rate stood at $4.5 \%, 19.6 \%, 3.1 \%, 31.7 \%$ and 121.75 respectively. The external debt stood at the average value of 23.6 billion dollars with debt servicing of 2.7 billion dollars on the average. The unit root test was done using augmented dickey fuller and the result shows that variables are stationary at level and at first difference. The study adopted ordinary least square techniques for the regression analysis. The result shows that external debt has negative and insignificant impact on economic growth in Nigeria. The granger causality also shows that external debt has no causal relationship with economic growth in Nigeria. This implies that external debt does not affect economic growth in Nigeria. This finding is in consonance with Ogunmuyiwa (2011). However, it 
does not agree with Ajayi and Oke (2012) who found a positive relationship between external debt and economic growth.

Nevertheless, this study observed that external debt servicing has negative and significant impact on economic growth in Nigeria. This implies that government should be conscious of borrowing since its repayment or servicing has negative impact on economic growth. The coefficient reveals that holding other regressors constant, a one percent rise on debt servicing on the average will lead to -0.134486 (representing 13.4\%) reduction on economic growth annually. This study also finds out that inflation has negative and significant impact on economic growth. This means that inflation does not contribute to economic growth in Nigeria. It is therefore necessary to make sure that there is price stability. In addition, foreign direct inflow has positive and significant impact on economic growth in Nigeria. FDI promotes economic growth in Nigeria. It is important that government provide enabling business environment which draws investors from abroad. This finding supports the works of Sakyi, Commodore and Opoku (2015) and Javaid (2016) who found out that foreign direct investment inflow triggers economic growth.

The study also finds out that gross fixed capital formation has positive significant impact on economic growth in Nigeria while real exchange rate has negative and insignificant impact on economic growth in Nigeria. This implies that real exchange rate does not account for economic growth in Nigeria.

Finally, the study obtained a reliable goodness of fit (0.914424) and the overall model is generally significant.

\section{Conclusion and Policy Recommendations}

\subsection{Conclusion}

In determining the impact of external debt on economic growth in Nigeria, the study concluded that external debt has negative and insignificant impact on economic growth in Nigeria. Furthermore, the study sought to examine causality between external debt and economic growth in Nigeria using the granger causality test. The test showed that external debt had no causal relationship with economic growth in Nigeria. Finally, in identifying the impact of external debt servicing on economic growth in Nigeria, the study found out that the probability of external debt servicing is less than five percent and with negative sign. This implies that we reject the null hypothesis and conclude that external debt servicing has negative and significant impact on economic growth in Nigeria.

In other major findings, the study concludes that external debt servicing and inflation have negative and significant influence on economic growth in Nigeria. Whereas, foreign direct investment and gross fixed capital formation have positive and statistically significant impact on economic growth in Nigeria. However, the study finds that external debt and real exchange rate we no significant impact on Nigeria's economic growth. 


\subsection{Recommendations}

In line with the major findings generated from this study, this researcher offers the following recommendations.

1) Firstly, from the study, external debt servicing has negative significant impact on economic growth. There is need for the government to diversify our monolithic economy as this will help to generate more revenue and reduce the effect of down trend in the oil revenue which usually calls for debt.

2) Secondly, the government through monetary authority (Central Bank of Nigeria) should carefully monitor the economy and make sure that inflation which pose worry is reduced to the barest minimum.

3) Finally, the government should continue to encourage foreign direct investment in order to bring more inflows that will trigger economic growth.

4) There should be enabling business environment (devoid of insecurity, high tax rates, and so on) so as to promote both local and foreign investment in order to increase capital formation and consequently economic growth.

\section{Conflict of Interest Statement}

The authors declare no conflicts of interests.

\section{About the Authors}

Timothy Ogbemudiare Ideh is a researcher in the department of economics, Nnamdi Azikiwe University Awka, Anambra State, Nigeria. His interest is in monetary economics. He is Master's degree holder in Economics.

Uzonwanne, Maria Chinecherem is currently a senior lecturer in department of Economics, Nnamdi Azikiwe University Awka, Anambra State, Nigeria. She is a PhD holder in economics and specializes in development economics.

\section{References}

Adesola, W. A. (2009). Debt servicing and economic growth in Nigeria: An empirical investigation. Global Journal of Social Sciences, 8(2), 1-11.

Agarwal, P. (2019). Economic growth and development. International Journal of Economics and Research, 5(1), 1-9.

Ajayi, L. B. \& Oke, M. O. (2012). Effect of external debt on economic growth and development of Nigeria. International journal of business and Social Science, 3(12), 297-304.

Amakom, U. S. (2003). Nigeria public debt and economic growth: An empirical assessment of effects on poverty. African Institute for Applied Economics, 2(4), 43-58.

Anyanwu, J. C. \& Oaikhenan, H. E. (1995). Modern macroeconomics: Theory and applications in Nigeria. Benin, Nigeria: Department of economics and statistics, university of Benin. 
Arnone, M., Bandiera, L., \& Presbitero, A. (2005). External debt sustainability: theory and empirical evidence. Retrieved from http://www3.umcatt.it/dipartmenti/DISES/allegati/ArnoneBandicraPresbitero .pdf

Ayadi, F. S. \& Ayadi, P. O. (2008). The Impact of external debt on economic growth; A comparative study of Nigeria and South Africa. Journal of Sustainable Development in Africa, 10(3), 234-264.

Berhanu, G., \& Ersumo F. (2020). The Impact of Public External Debt on Economic Growth in Ethiopia: The ARDL Approach to Co-integration, Journal of Economics and Sustainable Development, 11(11), 25-40

CBN (2010). Annual report and statement of accounts. CBN Statistical bulletin. Retrieved from www.xbii.gov.ng/documents/

CBN (2015). Annual report and statement of accounts. CBN Statistical bulletin. Retrieved from www.cbn.gov.ng/docunients/

Clements B., Bhattacharya, R., \& Nguyen, T. Q. (2003). External debt, public investment and growth in low-income countries. IMF Working paper, No 03/249.

Cohen, D. (1993). Low investment and large LDC debt in the 1980s. American Economic Review. 83(3).

Corporate finance institute (2021). What is External Debt? Available at https://corporatefinanceinstitute.com/resources/knowledge/credit/external-debt/ (assessed 09/09/2021)

Debt Management Office (DMO) (2004). Annual Report and Statement of Account, Abuja. Debt Management Office (DMO) (2009), Annual Report and Statement of Account, Abuja.

Engel, R. \& Granger, C. (1987). Co-integration and error correction: Representation, estimation, and testing. Econometrica, 55(2), 251-276. Retrieved from https://www.istor.org/Mtabic/1913236

Ezeabasili, V. N., Isus H. O., \&Mojekwu, J. N. (2011). Nigeria's external debt and economic growth: An error correction approach. International journal of business and Management. 6(5), 156-170.

Gujarati, D. \& Porter, D. (2009). Basic Econometrics (5 ${ }^{\text {th }}$ ed.). New York, NY: McGraw Hill Inc.

Hameed, H., Ashraf \& Chaudary, M. A. (2008). External Debt and its Impact on Economic and Business Growth in Pakistan. International Research Journal of Finance and Economics. 3(20), 132-140.

Hassan, M. O., Sule, A., \& Abu, J. (2015). Implications of external debt on the Nigerian economy: Analysis of the dual gap theory. Journal of Economics and Sustainable Development, 6(13), 238-248.

Ibi, E. E. \& Aganyi, A. (2015). Impacts of external debt on economic growth in Nigeria: A VAR approach. Journal of Business Management and Administration. 3(1), 1-5.

Ijirshar, V. U., Joseph, I., \& Godoo, M. (2016). The relationship between external debt and economic growth in Nigeria, international Journal of Economics $\mathcal{E}$ Management Sciences. $4(8)$. 
Izedonmi, F. I. O, \& Ilaboya, O. J. (2012). Public debt-growth dynamics: The Nigerian experience. Journal of Research in National Development. 10(3).

Javid, W. (2016). Impact of foreign direct investment on economic growth of Pakistan an ARDL-ECM Approach. Journal of Finance and Economics, 5(4), 156-163.

Jhingan, M. L. (2005). The economics of development and planning. New Delhi; Delhi Vrinda Publications Inc.

Jhingan, M. L. (2010). Macroeconomics theory (I2'h ed.). New Delhi: Delhi Vrinda Publications Inc.

Kenton, W. (2018). External debt: Determinants of external debt. International Journal of Statistics and Economics. 14(6), 112-121.

lyoha, A. M. (1999). External debt and economic growth in sub-Saharan African countries: An econometric study. AERC Research Paper 90 African Economic Research Consortium, Nairobi 7(2), 55-73.

Mba, Peter N., Bell-Gam, M. A., \& Ubi, P. S. (2012). Interplay of foreign aids, external debt and economic growth: the Nigeria experience. International Journal of Economics and Finance. 4(8), 56-70.

Mhah, S. A., Agu, O. C., \& Urnunna, G. (2016). Impact of external debt on economic growth in Nigeria: An ARDL bound testing approach. Journal of Economics and Sustainable Development. 7(10), 16-26

Muhammad, U. D. \& Fayyaz, A. (2015). External debts and exchange rates of oil producing and I non-oil producing Nations: evidence from Nigeria and Pakistan. Journal of Advanced Management Sciences. 3(1), 8-12.

Nairametrics (2020). Nigeria's foreign debt has breached a 15-year trigger https://nairametrics.com/2020/04/11/nigerias-foreign-debt-has-breached-a-15year-trigger/ (Assessed 21/04/2021)

Nakatani, P. \& Herrera, R. (2007). The south has already repaid its debt to the north, but the north refuses to recognize its debts to the south. CES Working paper. 2007 (12).

Obadan, M. I. (2004). Foreign capital flows and external debt, perspectives on Nigeria and the LDCs Group. National Centre for Economic Management and Administration. $8(4), 42-51$.

Ogbeifun, L. B. (2007). Effects of petroleum products pipeline vandalism on society., employee and organizational productivity: the dilemma of downstream operation in Nigeria. Journal of Economics and Sustainable Development. 5(8), 22-34.

Ogunmuyiwa, M. S. (2011). Does external debt promote economic growth? Current Research Journal of Economic Theory. 3(1), 29-35.

Okonjo-Iweala, N., Soludo, C. \& Muhtar, M. (eds.) (2003). The Debt Trap in Nigeria. Trenton NJ: Africa World Press Inc.

Olasode, O.S. \& Babatunde, T.S. (2016). External debts and economic growth in Nigeria: An empirical study using autoregressive distributed lag model. Business and Economics Journal 6(3), 37-43.

Oloyede, B. (2002). Principles of International Finance. Forthright Educational Publishers, Lagos. 
Paul, N. (2017). Analysis of the impact of external debt on economic growth in an emerging economy: Evidence from Nigeria African Research Review. 11(4), 156-173.

Rifaqat, A. \& Usman, M. (2012). External debt accumulation and its impact on economic growth in Nigeria. The Pakistan Development Review. 51(4), 79-95.

Sakyi, D., Commodore, R. \& Opoku, E. (2015). Foreign direct investment, trade openness and economic growth in Ghana: An empirical investigation. Journal of African Business, 16(1), 1-5

Sanusi, J. O. (2003). Management of Nigeria's domestic debt.7th Monetary policy forum by the Central Bank of Nigeria, Abuja.

Serieux, J. \& Samy, Y. (2001). The debt service burden and growth: Evidence from low income countries. Paper prepared for the WIDER Development Conference on Debt Relief, 17-18 August 2001, Helsinki

Sulaiman, L. A. \& Azeez, B. A. (2012). Effect of external debt on economic growth of Nigeria. Journal of Economic and Sustainable Development. 3(8), 73-82.

Todaro, M. \& Smith, S. (2011). Economic development (12 ${ }^{\text {th }}$ ed.). Washington D.C: George Washington University Management.

Udoffia, D. T. \& Akpanah, E.A. (2016). An assessment of the impact of external debt on economic growth of Nigeria. International Journal of Social Sciences. 10(1), 1-27

Ugwuegbe, S. U., Okafor, I. G., \& Akarogbe, C.A. (2016).Effect of external borrowing and foreign aid on economic growth in Nigeria International Journal of Academic Research in Business and Social Sciences, 6(4), 155-175.

Utomi, O. W. (2014). The impact of external debt on economic growth in Nigeria. International Journal of Economics and Finance. 4(8), 48-59.

World Bank Statistics (WDI, 2019). 
Creative Commons licensing terms

Authors will retain copyright to their published articles agreeing that a Creative Commons Attribution 4.0 International License (CC BY 4.0) terms will be applied to their work. Under the terms of this license, no permission is required from the author(s) or publisher for members of the community to copy, distribute, transmit or adapt the article content, providing a proper, prominent and unambiguous attribution to the authors in a manner that makes clear that the materials are being reused under permission of a Creative Commons License. Views, opinions and conclusions expressed in this research article are views, opinions and conclusions of the author(s).Open Access Publishing Group and European Journal of Economic and Financial Research shall not be responsible or answerable for any loss, damage or liability caused in relation to/arising out of conflict of interests, copyright violations and inappropriate or inaccurate use of any kind content related or integrated on the research work. All the published works are meeting the Open Access Publishing requirements and can be freely accessed, shared, modified, distributed and used in educational, commercial and non-commercial purposes under a Creative Commons Attribution 4.0 International License (CC BY 4.0). 